\title{
Appropriate Selection of materials for making durable Self Compacting Concrete And application in Underground Structures
}

Sandip Sonule ( $\sim$ sandipsonule47@gmail.com )

Shanghai Tunnel Engineering Co., Ltd

\section{H.Jayarama}

Larsen \& Toubro

\section{Partha Sarath Ojha}

Shanghai Tunnel Engineering Co., Ltd

\section{C.M Jadhav}

Mumbai Metro Rail Corporation Ltd

\section{Case Report}

Keywords: Flowable Concrete, Concrete Mix Design, Fresh \& Hardened Properties of concrete, Durability, Application in the structure Posted Date: July 20th, 2021

DOI: https://doi.org/10.21203/rs.3.rs-701160/v3

License: (c) (i) This work is licensed under a Creative Commons Attribution 4.0 International License. Read Full License 


\section{Abstract}

Appropriate selection of materials plays an important role in concrete mix design for achieving the requirement of self-compacting concrete and ensuring a balance between deformability and stability. The type of selected materials and the ratios of concrete ingredients can be affected by the fresh and harden properties of the concrete. In the contract agreement of the Mumbai metro underground project, the technical specifications clearly state the values of limits set for achieving the durability parameters for the life of 120 years of the structure. According to the requirement of the site conditions Self-compacting concrete was designed with easily available material, special material like Ultra GGBS- Alcofine 1203 and crystalline waterproofing admixture. Self-compacting concrete is superior concrete than the traditional concrete with high workability, no segregation, no bleeding, and it is also suitable for use in structures with long-distance pumping i.e., more than 120-meter length, for For example, in Underground NATM tunnels, crosspassages, and the concrete structure of the underground metro station box. The paper presents a comparison between concrete mix designs and their achieved test parameters suitable for the contract agreement of the Mumbai metro underground project. The best concrete mix design for Self-compacting concrete was finalized based on flowability, passing ability, segregation resistance, and durability parameters of concrete mix and the same mix is implemented at the site for working structures.

\section{Introduction}

The Mumbai Metro underground project is designed for 120 years of life of concrete structures. In the agreement the technical specifications clearly state the values of limits set for achieving the durability tests parameters like RCPT, Water permeability, etc. Appropriate selection of supplementary cementitious materials such like GGBS, Ultrafine GGBS-Alccofine, Crystalline growth admixture etc., are required for improving durability, decreasing permeability, surface finish ability, and improving the overall hardened properties of concrete. Rheological properties of Self-compacting concrete is advanced than traditional normal slump concrete and the hardened properties of concrete are the same as traditional normal slump concrete. Self-compacting concrete is suitable for a fast rate of concrete placement, with faster construction times and ease of flow around dense reinforcement without vibration or a little bit of surface tamping to get a better surface finish. It ensures good homogeneity, pumping ability, best surface finish, consistent concrete strength, and durability of the concrete structure. "The workability of concrete describes the flowability, mobility, and stability of fresh concrete.

The hardened concrete properties like compressive strength, flexural strength, split tensile, etc. Are specifically struck by the composition of concrete ingredients. In the Mumbai region, river sand is not available and therefore construction industries are totally depending on manufactured sand. In M-sand it is difficult to maintain required fractions of sieve sizes for getting the appropriate zone of sand i.e., zone II as per IS383:2016 [2]. According to site requirements, only Self-compacting concrete was suitable due to long-distance pipe pumping and congested reinforcement in the structure. Hence Self-compacting concrete was developed by conducting several numbers of concrete mix trials and found that appropriate selection of materials is required for optimizing concrete mix design with low cementitious content and for achieving standards requirements for flowability by slump flow, and sieve segregation resistance tests as per specification mentioned in European standard [3]. Chemical admixtures i.e., high-performance superplasticizers required for optimized the cementitious content and minimize the W/C ratio for production of Self-compacting concrete [4].

\section{Concrete Ingredients}

\subsection{Cement}

OPC 53 Grade cement of M/s Ultratech is used. Physical \& Chemical tests results values are as given in Table $1 \& 2$ [1].

\subsection{GGBS}

Ground granulated blast furnace slag (GGBS) of M/s JSW obtained from Pen, Raigad, Maharashtra, India. The physical and chemical properties of GGBS are given in the Table 1 and Table 2, respectively [1].

\subsection{Ultrafine GGBS -Alccofine}


Ultrafine GGBS commercially available as Alccofine-1203 is a low calcium silicate-based mineral additive which is generally used as a replacement of silica fume in high-performance concrete [5]. Alccofine 1203 is a slag based SCM having ultra-fineness with the optimized particle size distribution [6].

Table 1. Physical Properties of Cement, GGBS and UGGBS-Alcofine 1203 [1]

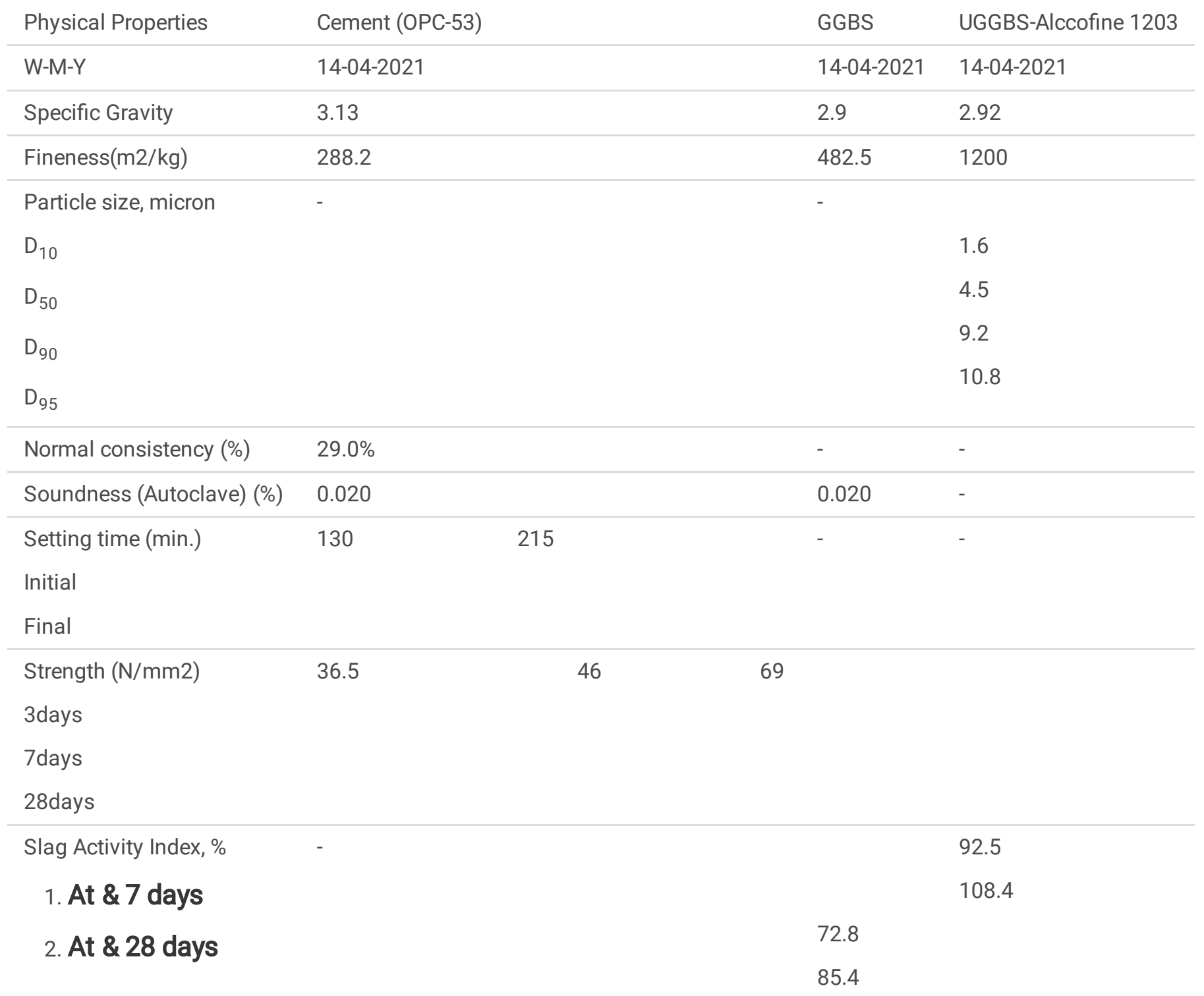

Table 2. Chemical Properties of Cement. GGBS and UFGGBS-Alccofine 1203 [1] 


\begin{tabular}{llll} 
Chemical Properties & Cement & GGBS & UGGBS-Alccofine 1203 \\
\hline Loss on ignition, \% by mass & 2.98 & 0.10 & 0.32 \\
\hline Glass content, \% by mass & - & 87.24 & 86.92 \\
\hline Magnesium Oxide (MgO) & 1.76 & 0.17 & 7.56 \\
\hline Total Sulphur (SO3), \% by mass & 2.9 & 0.25 & 0.22 \\
\hline Insoluble residue, \% by mass & 0.93 & - & - \\
\hline Alkali Content, \% by mass & 0.22 & 0.2 & 0.22 \\
\hline Total Chloride content, \% by mass & 0.017 & 0.011 & 0.015
\end{tabular}

"Ordinary Portland Cement OPC-53 grade, GGBS and UGGBS-Alccofine are conformed to Indian Standard Specifications IS: 2692015, IS 16714-2018and IS 16715-2018" [7] [8] [9]

\subsection{Chemical admixtures and crystaline growth waterproofing admixture}

"Poly carboxylic ether-based superplasticizer admixture brand name Sika ViscoCrete $5138 \mathrm{M} / \mathrm{s}$ Sika are used to bring out the required water reduction and maintain the dispersing effect during the time required for transportation and placement at the site.Sika ViscoCrete 5138 is a high-performance superplasticizer (H.P.S) and specially developed for high workability, flowable, and selfcompacting concrete mix. In the product data-sheet of Crystalline growth waterproofing admixture brand name SIKA $101 \mathrm{H}$ of M/s Sika. The use of crystalline waterproofing admixtures (CWA) has the potential of improving the durability and reducing the permeability of concrete structures especially those exposed to environments like soil face structures of underground structures" [10]

Table 3. Physical Properties of high-performance superplasticizer and crystalline admixtures

\begin{tabular}{|lll|}
\hline Characteristics & (H.P.S) Product Name-Sika ViscoCrete 5138 & C.W.A-Product Name \\
\hline Density (kg/lit) & & Sika 101 H \\
\hline Appearance & 1.125 & 1.3 \\
\hline pH & Brown & Gray Powder \\
\hline Dry material content & 6.43 & - \\
\hline Chloride (as Cl), \% by Mass & 42.49 & - \\
\hline Dosage (\%) by mass of cement & $<0.01$ & $<0.01$ \\
\hline Permeability to water vapor at 3 bar pressures & - & 0.8 to 1 \\
\hline Initial set time at 30 deg temperature & - & Impermeable \\
\hline
\end{tabular}

"Concrete admixtures are conformed to Indian Standard Specifications I S: 9103:1999" [11] and Crystalline Waterproofing admixture confirmed to manufacturer technical product data sheet.

\subsection{Aggregates}

In the Mumbai region, Maharashtra, India, river sand is not available, and therefore construction industries are totally depending on manufactured sand.

Coarse aggregate and Manufactured sand are obtained from the nearest source i.e., Kunde vahal, Panvel, Raigargh, Maharashtra. Fine aggregate- M/sand and coarse aggregate are conformed to Indian Standard Specifications IS: 383-2016 [2].

Table 5 shows the physical properties of the coarse and fine aggregates. 
Table 5. Physical Properties of Coarse and Fine Aggregates [1]

\begin{tabular}{|lll|}
\hline Physical tests & Coarse aggregate & $\begin{array}{l}\text { Fine aggregate } \\
\text { M-sand }\end{array}$ \\
\hline Specific gravity & 2.79 & 2.78 \\
\hline Water Absorption $(\%)$ & 1.89 & 2.91 \\
\hline Bulk density $(\mathrm{kg} / \mathrm{m} 3)$ & 1470 & 1730 \\
\hline
\end{tabular}

\section{Concrete Mix Design}

"The concrete mix is designed as per absolute volume method according to the Indian standard -Concrete mix proportioning Guidelines to meet environmental exposure conditions of Mumbai city, Maharashtra i.e., considered a severe condition" [12]. "The properties of the concrete ingredients differ from one state to another state of the same country, and it is totally depending on the actual environmental exposer condition of the site and quality of available concrete ingredients for making suitable concrete mix" [13]. Various concrete trials were conducted using different kinds of materials and found two concrete mixes are matching the requirement of self-compacting concrete as per the requirement of European guideline and durability parameters of the technical specification of contract agreement of underground metro projects.

Concrete mix compositions are presented in Table 6 \& Table No-7.

Table 6. Concrete Mix Proportions for Self-compacting concrete M40 Grade - TR 1.

\begin{tabular}{|c|c|c|c|c|c|c|c|c|c|}
\hline $\begin{array}{l}\text { Trial Mix } \\
\text { No }\end{array}$ & $\begin{array}{l}\text { Cement } \\
(\mathrm{Kg} / \mathrm{m} 3)\end{array}$ & $\begin{array}{l}\text { GGBS } \\
(\mathrm{Kg} / \mathrm{m} 3)\end{array}$ & $\begin{array}{l}\text { Powder } \\
(\mathrm{Kg} / \mathrm{m} 3)\end{array}$ & $\begin{array}{l}\text { W/P } \\
\text { Ratio }\end{array}$ & $\begin{array}{l}C . A \\
(K g / m 3)\end{array}$ & $\begin{array}{l}F . A \\
M-S a n d \\
(\mathrm{Kg} / \mathrm{m3})\end{array}$ & $\begin{array}{l}\text { C.A/FA ratio } \\
\text { (\%) }\end{array}$ & $\begin{array}{l}\text { Water } \\
(\mathrm{Kg} / \mathrm{m} 3)\end{array}$ & $\begin{array}{l}H . P . S \\
(\mathrm{Kg} / \mathrm{m} 3)\end{array}$ \\
\hline TR1 & 330 & 230 & 560 & 0.32 & 770 & 972 & $44 / 56$ & 179 & 8.1 \\
\hline
\end{tabular}

Table 6. Concrete Mix Proportions for Self-compacting concrete M40 Grade - TR 2.

\begin{tabular}{|c|c|c|c|c|c|c|c|c|c|c|c|}
\hline $\begin{array}{l}\text { Trial } \\
\text { Mix } \\
\text { No }\end{array}$ & $\begin{array}{l}\text { Cement } \\
(\mathrm{Kg} / \mathrm{m} 3)\end{array}$ & $\begin{array}{l}\text { GGBS } \\
(\mathrm{Kg} / \mathrm{m} 3\end{array}$ & $\begin{array}{l}\text { UGGBS } \\
\text { Alcofine } \\
1203 \\
(\mathrm{Kg} / \mathrm{m} 3)\end{array}$ & $\begin{array}{l}\text { Powder } \\
(\mathrm{Kg} / \mathrm{m} 3)\end{array}$ & $\begin{array}{l}\text { W/P } \\
\text { Ratio }\end{array}$ & $\begin{array}{l}C . A \\
(\mathrm{Kg} / \mathrm{m} 3)\end{array}$ & $\begin{array}{l}F . A \\
\text { M-Sand } \\
(\mathrm{Kg} / \mathrm{m} 3)\end{array}$ & $\begin{array}{l}\text { C.A } \\
\text { /FA } \\
\text { ratio } \\
(\%)\end{array}$ & $\begin{array}{l}\text { Water } \\
(\mathrm{Kg} / \mathrm{m} 3)\end{array}$ & $\begin{array}{l}\text { H.P.S } \\
(\mathrm{Kg} / \mathrm{m} 3)\end{array}$ & $\begin{array}{l}\text { C.W.A } \\
(\mathrm{Kg} / \mathrm{m} 3)\end{array}$ \\
\hline TR2 & 330 & 200 & 20 & 550 & 0.32 & 778 & 981 & $44 / 56$ & 176 & 7.7 & 5.50 \\
\hline
\end{tabular}

"Acceptable results achieved in concrete trial mix no-TR 1 and TR 2. Coarse aggregate content, fine aggregate content, and cementitious content were optimized, until a slump flow of $500-700 \mathrm{~mm}$ is achieved by a slump flow test. All tests were carried out in the order that the trial mix satisfies slump flow test and Sieve stability tests" [1].

\subsection{Test Procedures}

"Self-compacting concrete is able to flow under its self-weight without segregation, bleeding without vibration and these behaviors of concrete can be ensured by Flowability tests, and Sieve segregation resistance tests of concrete to determine the flowability, passing ability, and segregation resistance of Self -compacting concrete according to BS: EN 12350 Part 8, 9, 10, 11, and 12" [14] 
Comparison of fresh concrete and harden concrete tests was carried out for concrete trial mix no- TR $1 \&$ TR 2 and observed more difference in the results of fresh concrete properties tests and harden concrete properties test values.

Table 8. Comparative statement for fresh concrete properties of Self-compacting concrete M40 Grade, Trial Mix no TR 1\& TR 2 Trials for SCC were conducted for design time 3 hours and obtained results are presented below.

\begin{tabular}{|c|c|c|c|c|c|c|c|c|}
\hline Mix & $\begin{array}{l}\text { Slump flow } \\
(\mathrm{mm})\end{array}$ & $\begin{array}{l}T 500 \\
\text { (sec) }\end{array}$ & $\begin{array}{l}\text { V- } \\
\text { funnel } \\
\text { Tf (sec) }\end{array}$ & $\begin{array}{l}V \text { - } \\
\text { funnel } \\
\text { T5min } \\
\text { (sec) }\end{array}$ & $\begin{array}{l}\text { L-box } \\
\text { Blocking } \\
\text { ratio(H2/H1) }\end{array}$ & $\begin{array}{l}\text { U-box } \\
\text { Difference } \\
(\mathrm{mm})\end{array}$ & $\begin{array}{l}\text { Segregation } \\
\text { Resistance }\end{array}$ & Remarks \\
\hline TR1 & 540 & 5 & 21 & 32 & 0.75 & 32 & 7.9 & $\begin{array}{l}\text { Results are } \\
\text { satisfactory }\end{array}$ \\
\hline TR2 & 580 & 5 & 15 & 21 & 0.8 & 19 & 7.5 & $\begin{array}{l}\text { Results are found } \\
\text { more Satisfactory }\end{array}$ \\
\hline
\end{tabular}

Table 9. Comparative statement of Hardened Concrete Test results for self-compacting concrete trial mix no- TR 1\& TR 2.

\begin{tabular}{lllll}
$\begin{array}{l}\text { SI. } \\
\text { NO. }\end{array}$ & Test Description & $\begin{array}{l}\text { Acceptance Requirement as per contract } \\
\text { specification for Lab trial }\end{array}$ & $\begin{array}{l}\text { TR-1 Results } \\
\text { obtained }\end{array}$ & $\begin{array}{l}\text { TR-2 Results } \\
\text { obtained }\end{array}$ \\
\hline 1 & $\begin{array}{l}\text { Compressive Strength at } \\
28 \text { days }\end{array}$ & Target strength at the time of trial $-48.25 \mathrm{~N} / \mathrm{mm} 2$ & $48.34 \mathrm{~N} / \mathrm{mm} 2$ & $60.22 \mathrm{~N} / \mathrm{mm} 2$ \\
\hline 2 & RCPT & 1000 Coulombs & 782 coulombs & 503 coulombs \\
\hline 3 & Water Permeability & $10 \mathrm{~mm}$ & $6 \mathrm{~mm}$ & $2.33 \mathrm{~mm}$ \\
\hline 4 & Flexural strength & $>0.7 \sqrt{\mathrm{fck}}$ & $6.25 \mathrm{~N} / \mathrm{mm} 2$ & $7.3 \mathrm{~N} / \mathrm{mm} 2$ \\
\hline 5 & Split tensile strength & $>0.5 \sqrt{\mathrm{fck}}$ & & $5.62 \mathrm{~N} / \mathrm{mm} 2$ \\
\hline 6 & & $=3.87 \mathrm{~N} / \mathrm{mm} 2$ & $5.01 \mathrm{~N} / \mathrm{mm} 2$ & $0.016 \%$ \\
\hline 7 & Drying Shrinkage & $0.05 \%(\mathrm{Max})$ & & $0.026 \%$ \\
\hline 8 & Moisture Moment & $0.03 \%(\mathrm{Max})$ & $0.018 \%$ & $0.013 \%$ \\
\hline 8 & Chloride content & $0.5 \%(\mathrm{Max})$ & $0.34 \%$ & $0.29 \%$ \\
\hline
\end{tabular}

It has been observed that trial mix no- TR 1 has achieved all the parameters of acceptance criteria of the underground metro project contract specifications in the lab trials but some values observed very closed to the requirement like passing ability values of $L$ box, U-box, and compressive strength values of the lab trial. Hence obtained results values were compared and found trial mix no- TR 02 is far better than TR 1 and mix TR 02 is selected for working concrete at site.

Selected trial Mix no -2 for Self-compacting concrete M40 Grade (10 MSA) [1]

\begin{tabular}{|c|c|c|c|c|c|c|c|c|}
\hline \multirow{2}{*}{\multicolumn{2}{|c|}{ Cementitious ( $\mathrm{Kg}$ ) }} & & Water $(\mathrm{Kg})$ & Fine Aggregate & Coarse aggregate & \multirow[t]{2}{*}{$(10 \mathrm{MSA})(\mathrm{Kg})$} & \multirow{2}{*}{$\begin{array}{r}H . P . S \\
(K g)\end{array}$} & \multirow[t]{2}{*}{ C.W.A } \\
\hline & & & & M-Sand (kg) & & & & \\
\hline `Cement & GGBS & UGGBS & 176 & 981 & 778 & & 7.7 & \\
\hline 330 & 200 & 20 & & & & & & 5.5 \\
\hline
\end{tabular}

Table 10. Test Results of Selected trial Mix no -TR 02 for Self-compacting concrete M40 Grade in Laboratory [1] 


\begin{tabular}{|c|c|c|c|c|c|c|}
\hline Test Observation & Property & Acceptance Limits as per European Guideline & Initial & $1 \mathrm{hr}$ & $2 h r s$ & $\begin{array}{l}3 \\
h r s .\end{array}$ \\
\hline $\begin{array}{l}\text { Slump-flow class } \\
\text { SF1 }\end{array}$ & $\begin{array}{l}\text { Flowability/Filling } \\
\text { Ability }\end{array}$ & $\geq 520 \mathrm{~mm}, \leq 700 \mathrm{~mm}$ & 660 & 650 & 610 & 580 \\
\hline T500 & Viscosity Flowability & between 3-7 Sec & 4 & 4 & 4.5 & 5 \\
\hline V5min & viscosity Flowability & - & 15 & 18 & 22 & 21 \\
\hline V Funnel Tv & Viscosity Flowability & $\geq 7 \mathrm{~S}, \leq 27 \mathrm{~s}$ & 11 & 13 & 14 & 15 \\
\hline \multicolumn{7}{|l|}{ VF 2} \\
\hline L Box (H2/H1) & Passing Ratio & $\geq 0,75$ & 0.85 & 0.85 & 0.82 & 0.8 \\
\hline U Box Deference & Height difference & $30 \mathrm{~mm}$ Max & 0 & 14 & 18 & 19 \\
\hline $\begin{array}{l}\text { Sieve } \\
\text { Segregation }\end{array}$ & $\begin{array}{l}\text { Segregation } \\
\text { Resistance }\end{array}$ & $<23 \%$ & 9.5 & 9.2 & 8.4 & 7.5 \\
\hline $\begin{array}{l}\text { Ambient } \\
\text { Temperature }\end{array}$ & & & 26.5 & 27.5 & 28.2 & 29.4 \\
\hline
\end{tabular}

"Mix proportion of selected mix design TR5 implemented at the site for Tunnel NATM concrete and NATM cross passages and a total of 11426 cum concrete quantity is executed from 25th Feb 2020to 30th June'2021. The flowing ability and passing ability of concrete mix is checked according to conformity criteria for the properties of Self-compacting concrete at the site and observed results are as below" [3].

Table 11. The Average Test Results of Site executed Self-compacting concrete mix during concreting for Tunnel NATM Lining Concrete.

\begin{tabular}{|c|c|c|c|c|c|}
\hline $\begin{array}{l}\text { Test } \\
\text { Observation }\end{array}$ & Property & $\begin{array}{l}\text { Acceptance Limits as per } \\
\text { European Guideline }\end{array}$ & $\begin{array}{l}\text { Results } \\
\text { obtained at } \\
\text { Batching } \\
\text { Plant }\end{array}$ & $\begin{array}{l}\text { Results obtained } \\
\text { (around } 1 \text { to } 2 \text { hrs after } \\
\text { batching time) }\end{array}$ & $\begin{array}{l}\text { Remarks } \\
\text { (Comparison } \\
\text { with } 2 \text { hrs } \\
\text { results of } \\
\text { TR 9) }\end{array}$ \\
\hline $\begin{array}{l}\text { Slump-flow } \\
\text { class SF1 }\end{array}$ & $\begin{array}{l}\text { Flowability/Filling } \\
\text { Ability }\end{array}$ & $\geq 520 \mathrm{~mm}, \leq 700 \mathrm{~mm}$ & 630 & 560 & $\begin{array}{l}-40 \mathrm{~mm} \text { than } \\
\text { TR } 2\end{array}$ \\
\hline T500 & $\begin{array}{l}\text { Viscosity } \\
\text { Flowability }\end{array}$ & between 3-7 Sec & 4 & 6 & $\begin{array}{l}-1.5 \mathrm{sec} \text { than } \\
\text { TR2 }\end{array}$ \\
\hline V5min & $\begin{array}{l}\text { viscosity } \\
\text { Flowability }\end{array}$ & - & - & - & Not Taken \\
\hline $\begin{array}{l}\text { V Funnel TV } \\
\text { VF } 2\end{array}$ & $\begin{array}{l}\text { Viscosity } \\
\text { Flowability }\end{array}$ & $\geq 7 \mathrm{~S}, \leq 27 \mathrm{~s}$ & - & - & Not Taken \\
\hline $\begin{array}{l}\text { L Box } \\
(\mathrm{H} 2 / \mathrm{H} 1)\end{array}$ & Passing Ratio & $\geq 0,75$ & - & - & Not Taken \\
\hline $\begin{array}{l}\text { U Box } \\
\text { Deference }\end{array}$ & Height difference & $30 \mathrm{~mm}$ Max & - & - & Not Taken \\
\hline $\begin{array}{l}\text { Sieve } \\
\text { Segregation }\end{array}$ & $\begin{array}{l}\text { Segregation } \\
\text { Resistance }\end{array}$ & $<23 \%$ & - & - & Not Taken \\
\hline $\begin{array}{l}\text { Ambient } \\
\text { Temperature }\end{array}$ & & 26.5 & 27.5 & 28.2 & $\begin{array}{l}-1.2 \text { deg at } \\
\text { site }\end{array}$ \\
\hline
\end{tabular}

All the parameters of tests are not checked at the site due to the fact shifting of all checking out equipment could not nearly be possible at some point of concreting at the site, but slump flow, T $500 \mathrm{~mm}$ checks, and the temperature had been executed for 1904 transit mixers and their common values are cited in above table. 
Sample of concrete cubes of the working structures were taken as per requirements of contract technical specifications and results of 7 days, 28 days, and 56 days are presented in the table below.

Table 12. The Compressive Strength of site casted cubes for M40 grade Self-compacting concrete (in N/mm2) [1]

\begin{tabular}{|c|c|c|c|c|c|c|}
\hline $\begin{array}{l}\text { SI. } \\
\text { No }\end{array}$ & $\begin{array}{l}\text { Age of casted } \\
\text { Cubes }\end{array}$ & $\begin{array}{l}\text { No. } \\
\text { Samples }\end{array}$ & $\begin{array}{l}\text { Avg. Compressive Strength } \\
\text { of Samples in } \mathrm{N} / \mathrm{mm} 2\end{array}$ & $\begin{array}{l}\% \text { Of Compressive } \\
\text { Strength Gaining }\end{array}$ & $\begin{array}{l}\text { Standard } \\
\text { Deviation in } \\
\mathrm{N} / \mathrm{mm} 2\end{array}$ & $\begin{array}{l}\% \text { Of Coefficient } \\
\text { of Variation }\end{array}$ \\
\hline 1 & 7 days & 8 & 40.14 & 100.35 & \multirow[t]{3}{*}{1.82} & \multirow[t]{3}{*}{3.03} \\
\hline 2 & 28 Days & 35 & 60.22 & 150.55 & & \\
\hline 3 & 56 days & 8 & 65.09 & 162.73 & & \\
\hline
\end{tabular}

\section{Application Of Self-compacting Concrete In The Structure}

Following points had been ensured at the site before and during the placement of Self-compacting concrete.

- Assessment for the placement situations of Self-compacting concrete either by using boom placer, long distance pipe pumping, direct placing via a chute or a concrete bucket placement.

- Shutter has been designed for the capability and withstanding in the forces of lateral stress of fresh concrete.

- Concrete pour plans were prepared for every concrete pour for maintaining sequence of concrete production from batching plant, placing at site, movements of pump and pipe's location during concreting to maintain the concrete pour rate and avoid formation of cold joints.

- Quality control tests and checks at batching plant before despatching the concrete and same tests were performed at site also before pouring at the structure.

- Avoid direct free fall of concrete more than $1.5 \mathrm{~m}$ height.

- Throughout concrete pouring visible observation have been completed for segregation in the formwork and determined no segregation.

- Concrete pour rate became maintained to keep away from entrainment and to restriction the strain at the formwork.

- Shutter vibrators, needle vibrators were used according to placing condition to ease of flow and reach each corner of formwork and compaction for achieving smooth surface finish after de-shuttering.

\subsection{Quality Control Checks \&Concrete surface finish after De-shuttering of the Structure}

The appropriate technical and testing equipment team was deployed to the Batching plant, TM checkpoint and placement facility. Self-compacting concrete has been successfully applied to the construction of forms without interruption and inconveniences due to proper and systematic planning. After the De-shuttering of NATM tunnel lining, Cross passage and RCC walls concrete surfaces are found smooth.

\section{Conclusion}

1. Appropriate selection of concrete ingredients and optimization of powder content in concrete mix, helps to improve the results of flowability, passing ability without vibration in the structure and best results for durable parameters of the concrete.

2. Self-compacting concrete can be easily placed in long distance pumping and in obstacles due to dense reinforcement of structure without vibration during the placement.

3. Crystalline waterproofing admixture plays effective role for reducing permeability and increase durability of the structures.

4. Water permeability tests and RCPT values found less in low cementitious concrete i.e., TR 2 due to adding of crystalline waterproofing admixture as compared to high cementitious concrete trial mix no TR 1.

5. More impermeable and durable concrete can be developed in optimized cementitious content using crystalline waterproofing admixture in the concrete mix. 


\section{Declarations}

\section{Acknowledgment}

The authors are thankful to Director Projects of Mumbai Metro Rail Corporation and PMT Head of Shanghai Tunnel Engendering Co., Ltd for their motivational inputs and supports.

\section{Compliance with ethical standards}

Conflict of interest - On behalf of all authors, the corresponding author states that there is no conflict of interest.

\section{References}

[1] K. C. T. N. V. P. V. \&. A. B. G. Sandip Sonule, "A case study on performance of self-compacting concrete in highly congested reinforcement of cast in situ structure," Asian Journal of Civil Engineering, vol. 22, no. 4, pp. 1-10, June 2021.

[2] Chiara F. Ferraris, "Measurement of the Rheological Properties of High Performance Concrete: Sate of the Art Report," Journal of Research of the National Institute of Standards and Technology, vol. 104(5), no. 8, pp. pp.461-478, 1999.

[3] IS 383: 2016 Bureau of Indian Standards (New Delhi) Indian standard coarse and fine aggreagtes for concrete specification, IS 383: 2016.

[4] The European Guidelines for Self-Compacting Concrete Specification, Production and Use, May2005, 2005.

[5] A. I. Hassan EL-Chabib, "The performance of high-strength Self-compacting concrete made with binary," Construction and Building Materials 47 (2013) 245-253, vol. 47, no. 47, pp. pp 245-253, 2013.

[6] P. M. A. S. B. S. V. V. A. P. N. Ojha, "Optimization and evaluation of ultra high-performance con-crete," Journal of Asian Concrete Federation, vol. Vol. 6, no. No. 1, pp. pp. 26-36, June 2020, June 2020.

[7] M. V. a. P. D. b. V. K. c. B. Venkatesan a, "Experimental study on concrete using partial replacement of cement by," Materials Today: Proceedings, vol. Volume 37, no. Part 2, pp. Pages 2183-2188, 2021.

[8] IS 269:2015. Ordinary Portland Cement-Specification, 2015.

[9] IS 16714-2018. GGBS for use in cement, mortar and concrete-specifications, 2018.

[10] IS: 16715-2018 "Ultrafine Ground Granulated Blast Furnace Slag", 2018.

[11] C. Xue, "Self-healing efficiency and crack closure of smart cementitious composite with crystalline admixture and structural polyurethane," Construction and Building Materials, vol. Volume 260, p. 119955, November 2020.

[12] IS 9103:1999, Concrete Admixtures: Specification, Bureau of Indian Standard, Delhi, pp. 1-14., 1999.

[13] IS :10262:2009 Concrete mix proportioning - Guidelines, 2009.

[14] W. OH, "Why is SCC Different from Country. Fourth International Symposium on SCC," Chicago, 2005.

[15] MSZ EN 12350, Testing fresh concrete, Part 8, Part 9, Part 10, Part 11, Part 12, (2010), 2010.

[16] K. K. D. C. S. T. Patrick Paultre, "tructural performance of self-consolidating concrete used in confined concrete columns," ACl Struct J, 102 (7) (2005), pp. 560-568, vol. 7, no. 102, pp. pp. 560-568, 2005.

[17] A. D. Adesina, "Concrete Sustainability Issues," in 38th Cement and Concrete Science Conference, London, 2018.

[18] B. K. a. W. C. P. Steven H. Kosmatka, "Design and Control of concrete mixtures," Portland Cement Association, United States of America, 2008.

\section{Figures}




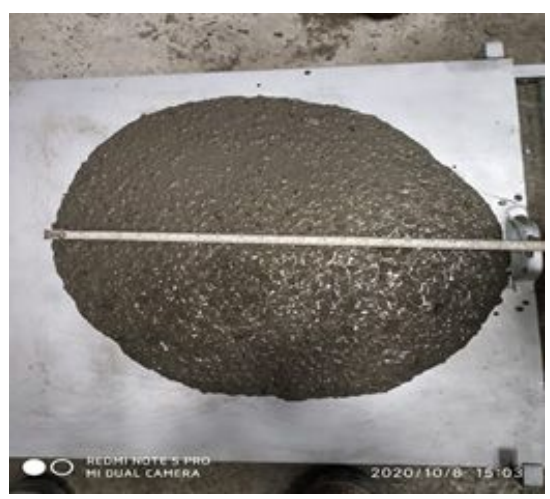

Figure 1

Slump Flow Test

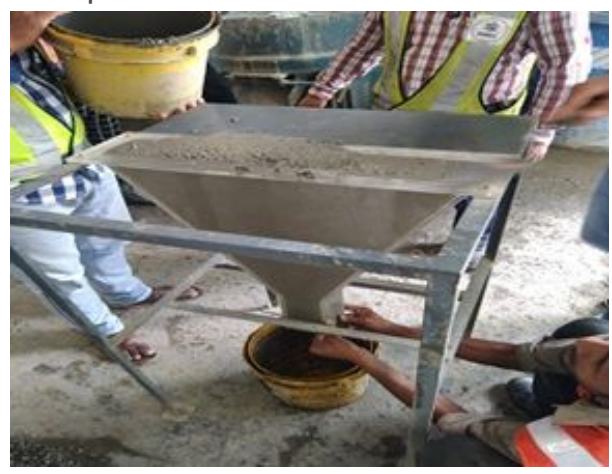

Figure 2

Funnel test

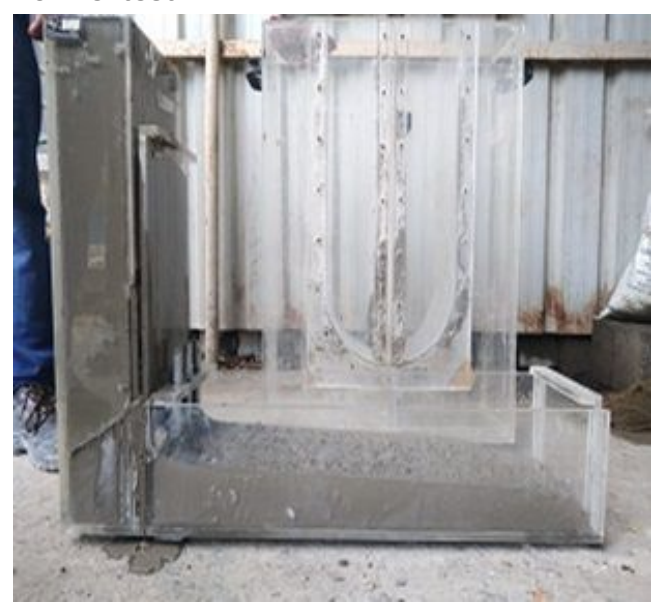

Figure 3

L-Box test 


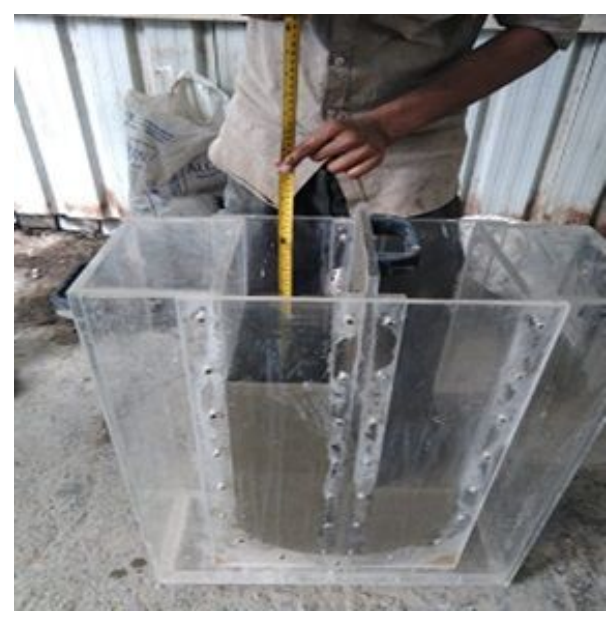

Figure 4

U-Box Test

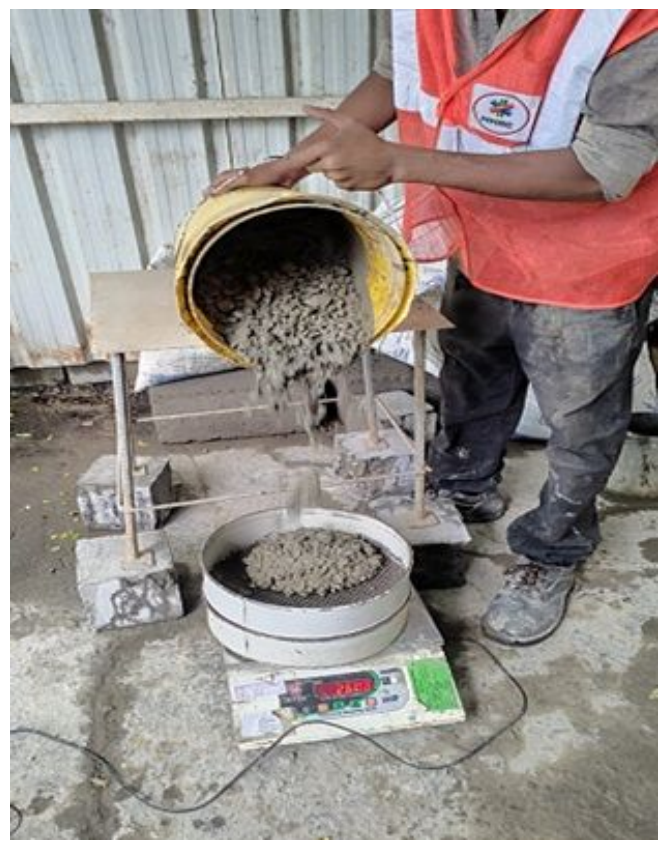

Figure 5

Sieve Segregation resistance Test

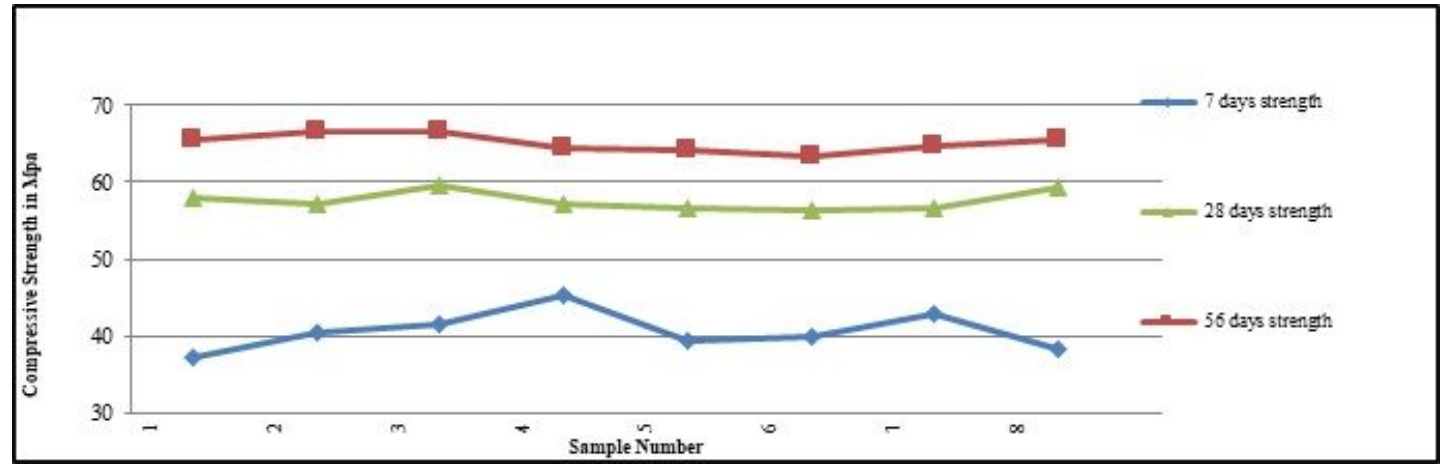

Figure 6

Strength of site casted cubes for 7 days, 28 days and 56 days 


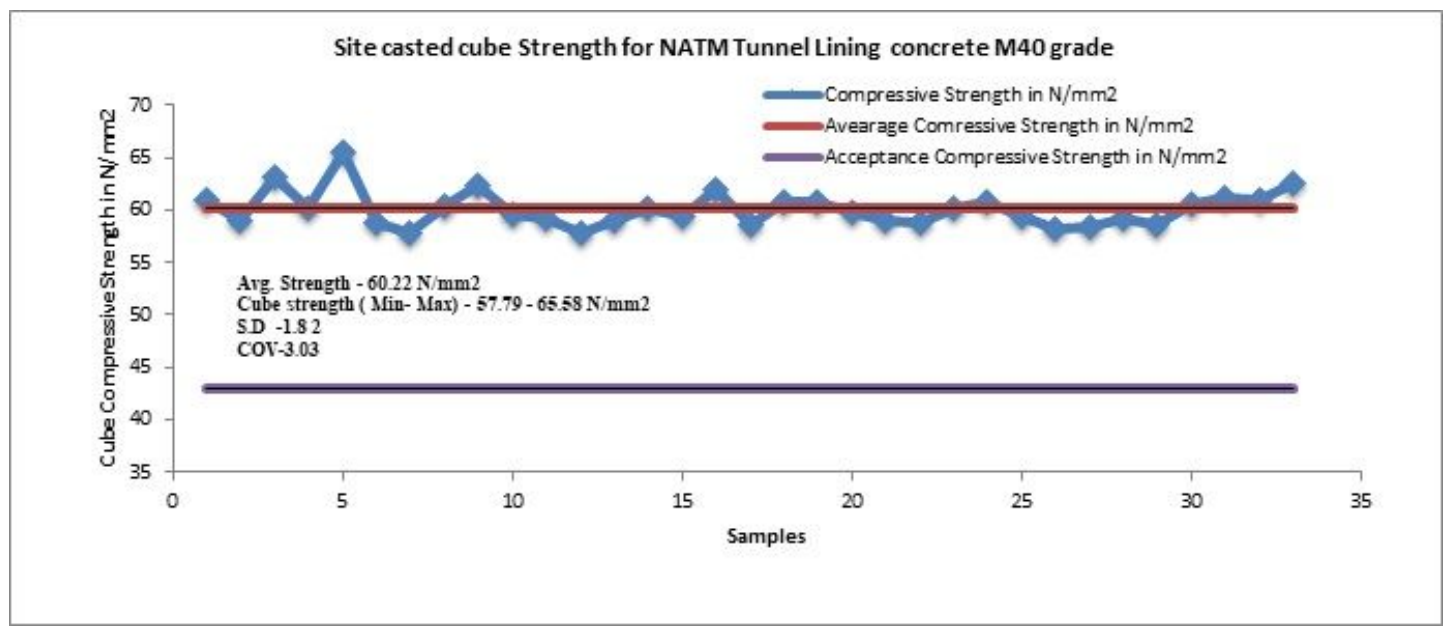

\section{Figure 7}

Graphical Representation of site casted Cube Compressive Strength for Tunnel NATM lining flowable concrete M40 Grade.

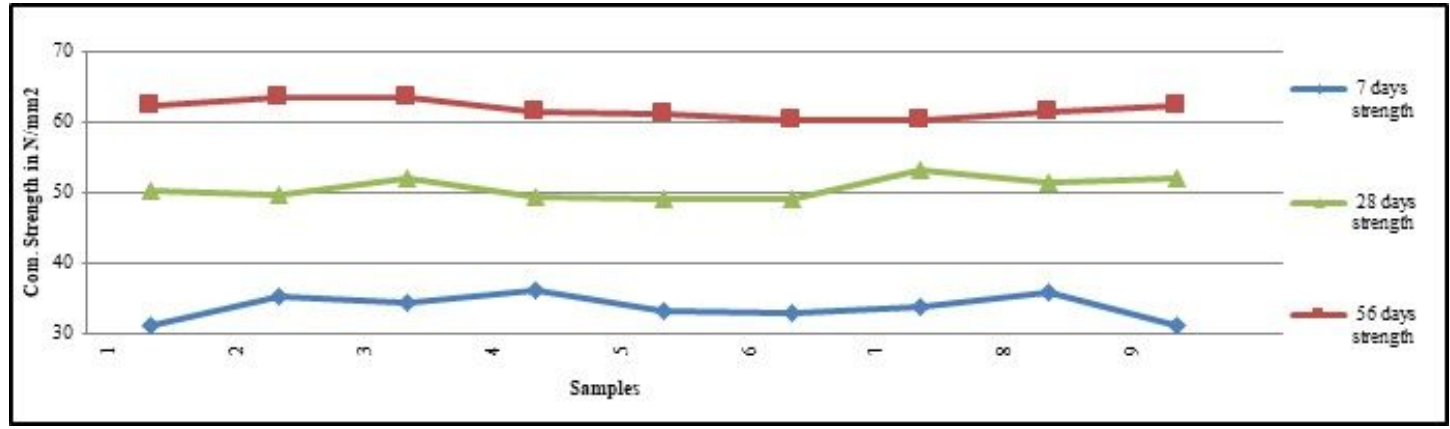

\section{Figure 8}

Graph showing Strength for flowable concrete M40 Grade for site casted cubes for 7 days, 28 days and 56 days.

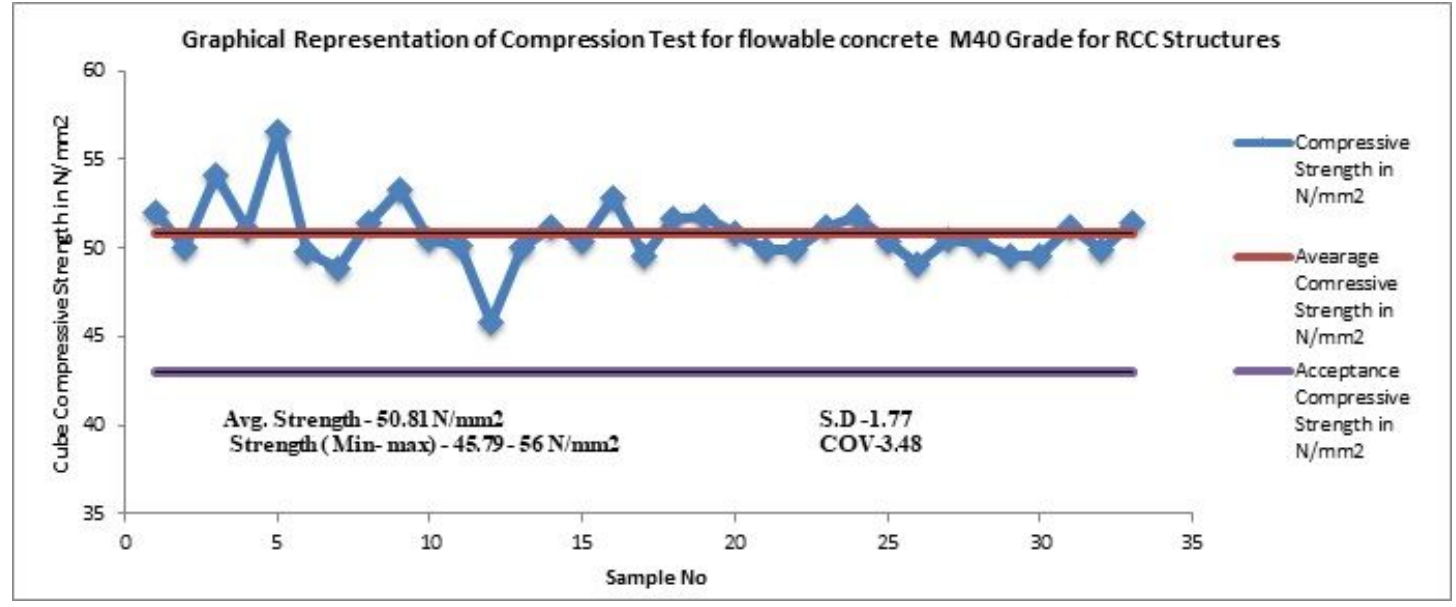

\section{Figure 9}

Graph showing Strength for flowable concrete M40 Grade for site casted cubes.
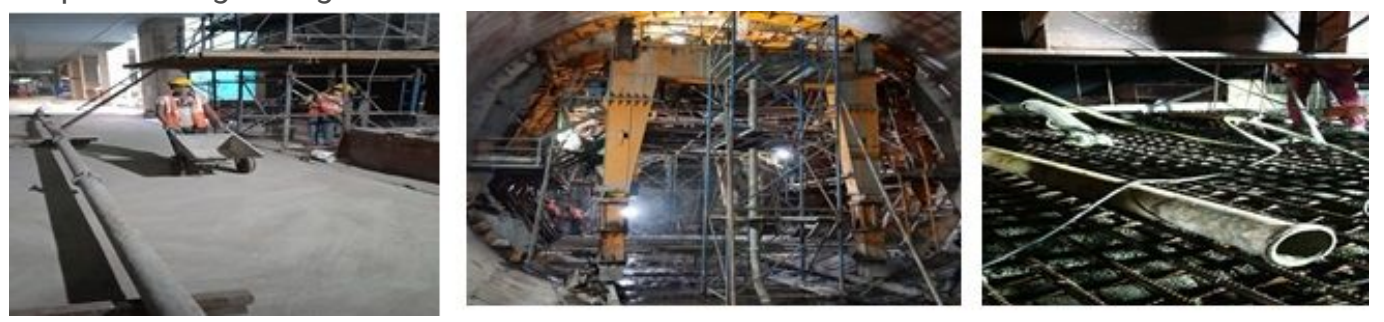


\section{Figure 10}

Actual site photographs during concrete placing at site showing two stages of concrete pouring and no's of bends to reach at placement point.
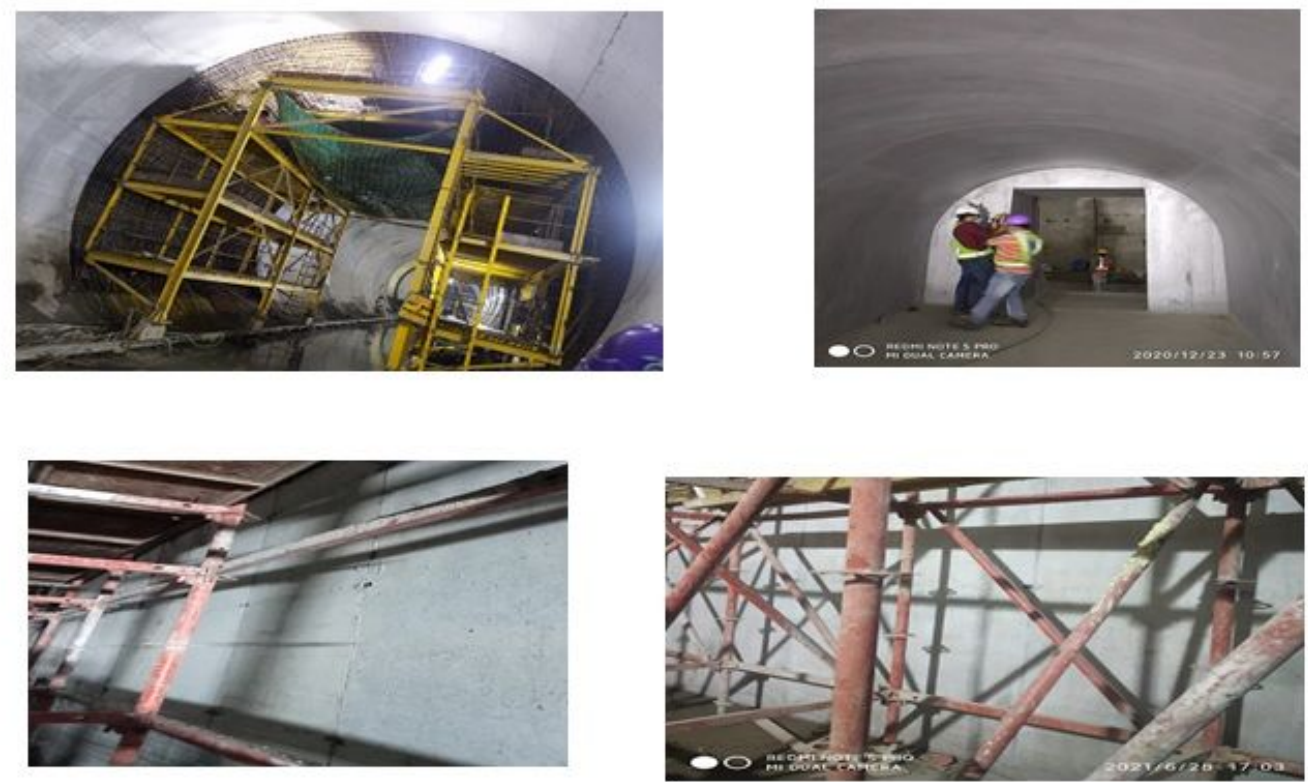

\section{Figure 11}

Smooth surfaces of the cast in situ flowable concrete

\section{Supplementary Files}

This is a list of supplementary files associated with this preprint. Click to download.

- 10mm.pdf

- 20mm.pdf

- Alcofine.pdf

- Cement.pdf

- Crushedsand.pdf

- GGBS.pdf

- M4010DliningMMDS.pdf

- M4010DliningWTRCPTFTST.pdf

- M40RCCFTandST.pdf

- M40RCCRCPTWTMMDS.pdf

- MixdesignApprovalM4010Dlining.pdf

- MixdesignApprovalM40RCC.pdf

- MumbaiReportsFM2104150207RSTM20394270421011109.pdf

- MumbaiReportsFM2104150207RSTNM20394270421011140.pdf

- MumbaiReportsFM2104150208RSTM20394270421011243.pdf

- MumbaiReportsFM2104150208RSTNM20394270421011351.pdf 